\title{
FOLIAR SPRAYING OF A SEAWEED-BASED BIOSTIMULANT IN SOYBEAN ${ }^{1}$
}

\author{
FABIANO ROSA MEYER ${ }^{2}$, VALDECI ORIOLI JÚNIOR ${ }^{2 *}$, JOÃO VICTOR SILVA BERNARDES ${ }^{2}$, VICTOR \\ PEÇANHA DE MIRANDA COELHO ${ }^{2}$
}

\begin{abstract}
Biostimulants currently available on the market include those containing seaweed extract. There is sufficient scientific evidence to conclude that applying biostimulants to agricultural crops can positively impact plant growth and yield. However, results differ between plants species and environmental conditions. As such, the present study aimed to assess the effects of doses and application times of a biostimulant based on seaweed (Ecklonia maxima) extract on the morphology and yield of soybean crops. The experiment was conducted in a field in the municipality of Uberaba, Minas Gerais state (MG), Brazil, in dystrophic red latosol. A randomized block design was used, with four repetitions, in a 3 x 5 factorial scheme consisting of three application times (phenological growth stages: V4, R1 and V4+R1) and five doses of foliarapplied biostimulant $\left(0,250,500,750\right.$ and $\left.1000 \mathrm{~mL} \mathrm{ha}^{-1}\right)$. In general, biostimulant application influenced the number of branches, nodes, flowers, and pods on the soybean plants and, consequently, crop yield. A dose of $607 \mathrm{~mL} \mathrm{ha}^{-1}$ promoted a $6.1 \%$ greater grain yield $\left(5379 \mathrm{~kg} \mathrm{ha}^{-1}\right)$ than that obtained without biostimulant spraying $\left(5070 \mathrm{~kg} \mathrm{ha}^{-1}\right)$. Application in stage R1 resulted in plants with more flowers and pods.
\end{abstract}

Keywords: Glycine max. Ecklonia maxima. Plant growth regulator.

\section{APLICAÇÃO FOLIAR DE BIOESTIMULANTE À BASE DE EXTRATO DE ALGA MARINHA NA CULTURA DA SOJA}

RESUMO - Dentre os bioestimulantes disponíveis no mercado, encontram-se aqueles compostos por extratos de algas. Já existem resultados científicos suficientes para se concluir que a aplicação destes bioestimulantes em culturas agrícolas pode afetar positivamente o crescimento e produtividade das plantas. No entanto, os resultados são discrepantes entre espécies vegetais e condições ambientais. Assim, objetivou-se avaliar os efeitos de doses e épocas de aplicação via foliar de bioestimulante à base de extrato de alga marinha (Ecklonia maxima) na morfologia e produtividade da cultura da soja. O experimento foi conduzido em campo no município de Uberaba - MG, em Latossolo Vermelho distrófico. O delineamento experimental foi em blocos casualizados, com quatro repetições, em esquema fatorial $3 \times 5$, sendo três épocas de aplicação (estádios fenológicos: V4, R1 e V4+R1) e cinco doses do bioestimulante $\left(0,250,500,750\right.$ e $\left.1000 \mathrm{~mL} \mathrm{ha}^{-1}\right)$ aplicadas via foliar. De modo geral, a aplicação do bioestimulante influenciou o número de ramos, nós, flores e vagens nas plantas de soja e, consequentemente, a produção da cultura. A aplicação de $607 \mathrm{~mL} \mathrm{ha}^{-1}$ do bioestimulante propiciou a maior produtividade de grãos $\left(5379 \mathrm{~kg} \mathrm{ha}^{-1}\right)$, que foi $6,1 \%$ superior à produtividade obtida sem aplicação do bioestimulante $\left(5070 \mathrm{~kg} \mathrm{ha}^{-1}\right)$. A aplicação no estádio R1 proporcionou plantas com quantidade maior de flores e vagens.

Palavras-chave: Glycine max. Ecklonia maxima. Regulador vegetal.

\footnotetext{
${ }^{*}$ Corresponding author

${ }^{1}$ Received for publication in $02 / 24 / 2020$; accepted in 09/08/2020.

Paper extracted from the master dissertation of the first author.

${ }^{2}$ Instituto Federal de Educação, Ciência e Tecnologia do Triângulo Mineiro, Uberaba, MG, Brazil; fabianomeyer@yahoo.com.br - ORCID: 0000-0002-4883-0746, valdeci@iftm.edu.br - ORCID: 0000-0001-6202-7100, joaovictorsilvabernardes@gmail.com - ORCID: 0000-00018522-3358, victorcoelho@iftm.edu.br - ORCID: 0000-0003-0024-3304.
} 


\section{INTRODUCTION}

Adequate flowering is important in soybean crops since it ensures a large number of pods and, consequently, high yields. However, given that abortion occurs in the early growth stages, not all flowers and pods remain on the plants and produce grain. Although this is a natural process that occurs even under ideal conditions, several factors influence the severity of flower and pod abortion, including environmental stress (THOMAS, 2018).

Adverse physiological reactions due to environmental stress can alter the availability of photoassimilates and nutrients, as well as the concentration of plant hormones such as abscisic acid and cytokinin, which are essential in controlling the fixation of soybean reproductive structures (LIU; JENSEN; ANDERSEN, 2004). Auxins also influence the number of reproductive structures on plants because they accumulate in developing pollen grains, likely promoting pollen germination on the stigma and triggering the rapid growth of pollen tubes (ALONI et al., 2006). These plant hormones can also be found in some products of biological origin, such as seaweed-based biostimulants (STIRK et al., 2004), which may affect flower and pod fixation.

Biostimulants are formulated products of biological origin that, due to the new or emerging properties of their components, promote better crop yields. Their use in agriculture has increased in an attempt to obtain higher yields, since biostimulants have been shown to regulate or modify plant physiological processes that promote growth, mitigate abiotic stress and increase yield (YAKHIN et al., 2017).

Seaweed extracts have been used as plant biostimulants (BATTACHARYYA et al., 2015; RENGASAMY et al., 2015). At low concentrations, these extracts can trigger a series of physiological changes and plant responses, such as promoting growth, increasing the number of flowers, improving salt, drought, and heat tolerance and, consequently, yield (BATTACHARYYA et al., 2015). The different types of seaweed-based biostimulants include those made from Ecklonia maxima, a brown kelp. Several studies have demonstrated the benefits of its application on plant growth and yield (KOCIRA; KORNAS; KOCIRA, 2013; BATTACHARYYA et al., 2015; RENGASAMY et al., 2015; KOCIRA et al., 2018).

Although data are available in the specialized literature, there are insufficient studies on its effect in Brazil to support future recommendations for agricultural crops. As such, this study aimed to assess the effect of doses and application times of a foliar-sprayed Ecklonia maxima-based biostimulant on the morphology and yield of soybean crops.

\section{MATERIAL AND METHODS}

The study was carried out in a field at the Federal Institute of Education, Science and Technology of Triângulo Mineiro (Uberaba Campus). Climate in the region is categorized as Aw according to Köppen's classification (BECK et al. 2018), with an average annual temperature and rainfall of $23.2^{\circ} \mathrm{C}$ and $1584 \mathrm{~mm}$, respectively. The daily rainfall and average temperatures recorded during the study period are shown in Figure 1.

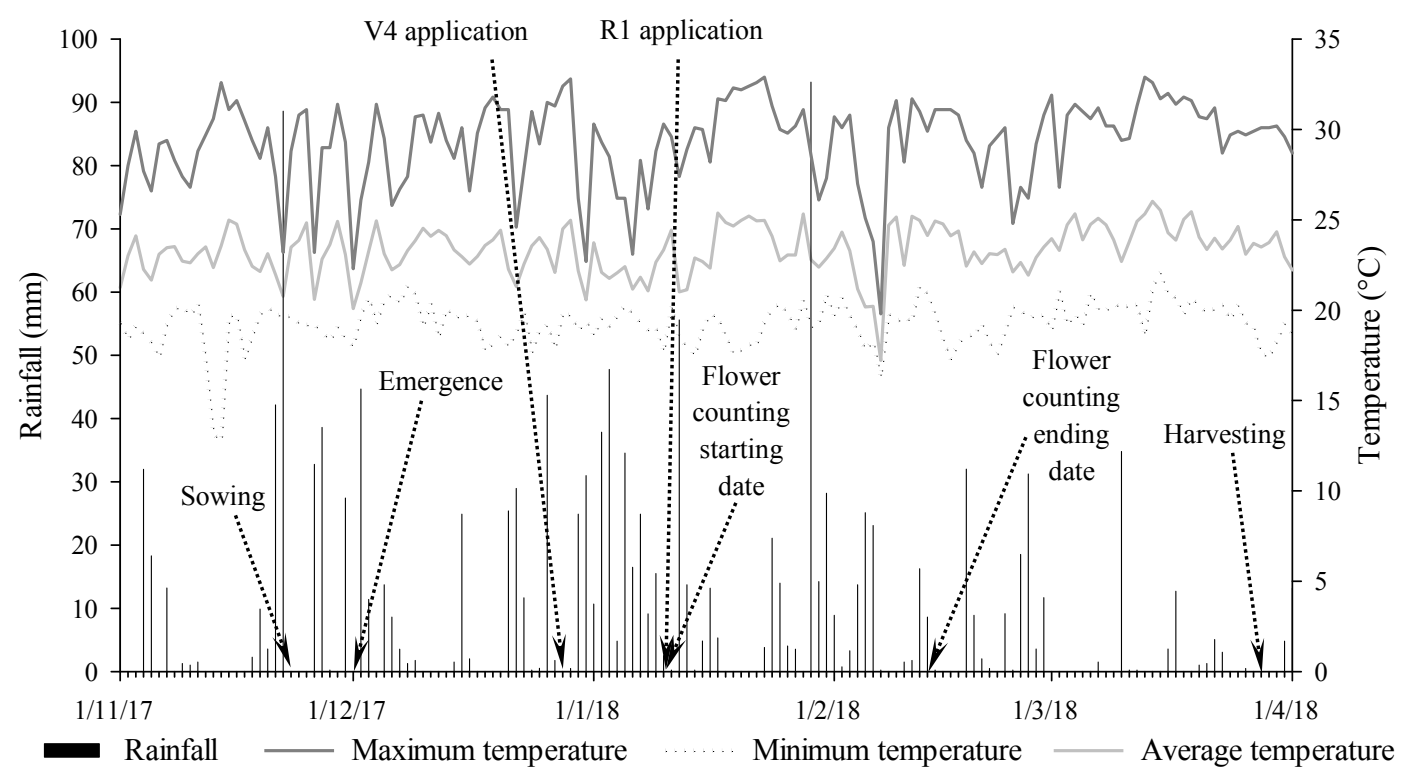

Figure 1. Daily rainfall and air temperatures during the study period. 
The experimental area has been used to grow maize and soybean for many years, with the former cultivated in the year prior to the experiment. Soil in the area was classified as medium-textured dystrophic red latosol (SANTOS et al., 2018), with the following chemical attributes in the $0-0.20 \mathrm{~m}$ layer: $\mathrm{pH}_{\mathrm{H} 2 \mathrm{O}}$ 5.3; $\mathrm{OM}=1.90$ dag $\mathrm{kg}^{-1}$; $\mathrm{P}_{\text {Mehlich-1 }}=69.9 \mathrm{mg} \mathrm{dm}{ }^{-3} ;$ P-rem $=32 \mathrm{mg} \mathrm{L}^{-1}$; $\mathrm{Ca}^{2+}=1.63 \mathrm{cmol}_{\mathrm{c}} \mathrm{dm}^{-3} ; \mathrm{Mg}^{2+}=0.46 \mathrm{cmol}_{\mathrm{c}} \mathrm{dm}^{-3}$; $\mathrm{K}^{+}=0.26 \mathrm{cmol}_{\mathrm{c}} \mathrm{dm}^{-3} ; \mathrm{B}=0.48 \mathrm{mg} \mathrm{dm}^{-3}$; $\mathrm{Cu}=1.1 \mathrm{mg} \mathrm{dm}{ }^{-3} ; \mathrm{Fe}=141 \mathrm{mg} \mathrm{dm}^{-3}$; $\mathrm{Mn}=21 \mathrm{mg} \mathrm{dm}{ }^{-3} ; \mathrm{Zn}=7.9 \mathrm{mg} \mathrm{dm}^{-3} ; \mathrm{H}+\mathrm{Al}=$ $3.66 \mathrm{cmol}_{\mathrm{c}} \mathrm{dm}^{-3}, \mathrm{Al}=0.11 \mathrm{cmol}_{\mathrm{c}} \mathrm{dm}^{-3} ; \mathrm{CEC}=$ $6.04 \mathrm{cmol}_{\mathrm{c}} \mathrm{dm}^{-3}, \mathrm{~V} \%=39.4$.

A randomized block design was used, with four repetitions, and a $3 \times 5$ factorial scheme consisting of three application times (phenological growth stages: V4, R1 and V4+R1) and five doses of foliar-applied biostimulant $(0,250,500,750$ and $\left.1000 \mathrm{~mL} \mathrm{ha}^{-1}\right)$. The plots were spaced $1 \mathrm{~m}$ apart and each consisted of eight 6-meter-long rows $\left(24 \mathrm{~m}^{2}\right)$, with the six center rows of each plot as the study area, disregarding $0.5 \mathrm{~m}$ at either end $\left(15 \mathrm{~m}^{2}\right)$.

The commercial biostimulant Booster ${ }^{\circledR}$ was used, with the following composition: $239 \mathrm{~g} \mathrm{~L}^{-1}$ of seaweed extract (Ecklonia maxima), $24.4 \mathrm{~g} \mathrm{~L}^{-1}$ of Mo and $36.6 \mathrm{~g} \mathrm{~L}^{-1}$ of $\mathrm{Zn}$. The seaweed extract used to manufacture the product contains $10.7 \mathrm{mg} \mathrm{L}^{-1}$ of auxins and $0.03 \mathrm{mg} \mathrm{L}^{-1}$ of cytokinins. Foliar applications were performed in the morning using a backpack sprayer, with a spray volume of $150 \mathrm{~L} \mathrm{ha}^{-1}$.

Before sowing, a sprayer was used to apply $2.0 \mathrm{~kg} \mathrm{ha}^{-1}$ of $\mathrm{Ca}\left(\mathrm{Cal}\right.$ Super $\left.^{\circledR}\right)$ and $0.3 \mathrm{~kg} \mathrm{ha}^{-1}$ of $\mathrm{Mg}$ $\left(\mathrm{Mag}\right.$ flo $^{\circledR}$ ) across the entire area. Potassium fertilizer $\left(140 \mathrm{~kg} \mathrm{ha}^{-1}\right.$ of $\left.\mathrm{K}_{2} \mathrm{O}\right)$, with potassium chloride as source $\left(60 \% \mathrm{~K}_{2} \mathrm{O}\right)$, was applied to the total area by broadcasting one day after sowing. Phosphate fertilization was not performed since the area contained enough phosphorus.

Sowing was carried out using the M6410 IPRO soybean cultivar (maturity group: 6.4; growth habit: indeterminate), targeting a final population of 300,000 plants per hectare. The seeds were treated with pyraclostrobin + thiophanate-methyl + fipronil $\left(\right.$ Standak Top ${ }^{\circledR}$ ), $0.33 \mathrm{~g} \mathrm{~kg}^{-1}$ of $\mathrm{Cu}, 0.17 \mathrm{~g} \mathrm{~kg}^{-1}$ of $\mathrm{Mo}$ and $1.50 \mathrm{~g} \mathrm{~kg}^{-1}$ of $\mathrm{Zn}$ (Broadacre $\mathrm{CMZ}^{\mathbb{B}}$ ), and inoculated with Bradyrhizobium japonicum $\left(\right.$ Vitaiz $\left.^{\circledR}\right)$.

Foliar applications were also performed in all the plots, as follows: $0.9 \mathrm{~g} \mathrm{ha}^{-1}$ of $\mathrm{Zn}$ and $76 \mathrm{~g} \mathrm{ha}^{-1}$ of $\mathrm{Mg}\left(\mathrm{Mag} \mathrm{flo}^{\circledR}\right.$ ) in stage V5; $75 \mathrm{~g} \mathrm{ha}^{-1}$ of B (Boro Super $\left.{ }^{\circledR}\right)$ in R1; $5 \mathrm{~g} \mathrm{ha}^{-1}$ of Mo and $4 \mathrm{~g} \mathrm{ha}^{-1}$ of $\mathrm{P}_{2} \mathrm{O}_{5}$ (Supa Moly ${ }^{\circledR}$ ), $170 \mathrm{~g} \mathrm{ha}^{-1}$ of $\mathrm{S}$ and $75 \mathrm{~g} \mathrm{ha}^{-1}$ of $\mathrm{N}$ $\left(\right.$ Supa $\left.\mathrm{S}^{\circledR}\right), 1650 \mathrm{~g} \mathrm{ha}^{-1}$ of $\mathrm{N}\left(\mathrm{Nitamin}^{\circledR}\right), 35 \mathrm{~g} \mathrm{ha}^{-1}$ of Fe (Big Red $\left.{ }^{\circledR}\right)$ in R3.

Weeds were controlled using glyphosate (Roundup Transorb ${ }^{\circledR}$ ) and disease managed by applying epoxiconazole + fluxapyroxad + pyraclostrobin $\quad\left(\right.$ Ativum $\left.^{\circledR}\right), \quad$ trifloxystrobin + prothioconazole $\left(\mathrm{Fox}^{\circledR}\right)$ and potassium phosphites
(Reforce ${ }^{\circledR}$ and Yantra ${ }^{\circledR}$ ). Pests were controlled with abamectin $\left(\right.$ Batent $\left.^{\mathbb{R}}\right)$, imidacloprid + beta-cyfluthrin $\left(\right.$ Connect $\left.{ }^{\circledR}\right)$, lambda-cyhalothrin (Karate Zeon $\left.^{\circledR}\right)$, lambda-cyhalothrin + thiamethoxan $\left(\right.$ Engeo Pleno $\left.{ }^{\mathbb{B}}\right)$.

The number of flowers on the stems, branches and whole plant was counted on three contiguous marked plants per plot. Counting was performed when the first flower emerged (stage R1) and continued weekly throughout flowering, for approximately five weeks.

At the end of the crop cycle, the number of pods containing grains was counted on these same plants. Next, flower establishment was calculated for the different plant parts (branches, stem and whole plant) and expressed as percentage. The number of branches per plant, number of nodes per branch and number of nodes on the stem were determined on these same plants.

Three days before harvesting, plant height was measured from the ground to apex, on 10 plants per plot, using a graduated ruler, and the final plant population determined by counting all the plants in each plot.

Once the plants reached physiological maturity, those from the four center rows were harvested and mechanically threshed, and the grains weighed to determine grain yield. Additionally, five subsamples of grain were collected per plot to calculate the 100 grain weight. The data for 100 grain weight and yield were corrected for a moisture content of $130 \mathrm{~g} \mathrm{~kg}^{-1}$ (wet basis).

Data were submitted to analysis of variance via the F-test and, when significant, the means between application times were compared using Tukey's test ( $\alpha=0.05$ ). Polynomial regression was performed for biostimulant doses. The statistical analyses were carried out using AgroEstat software (BARBOSA; MALDONADO JÚNIOR, 2010).

\section{RESULTS AND DISCUSSION}

The longest period without rain during the study was six days. Cumulative rainfall between sowing and harvesting was $1253 \mathrm{~mm}$, with $593 \mathrm{~mm}$ between plant emergence and the onset of flowering and approximately $381 \mathrm{~mm}$ during flowering (Figure $1)$.

Given that the total water requirement for optimal soybean yield is between 450 and $800 \mathrm{~mm}$ per cycle (EMBRAPA, 2013), there were no periods of prolonged drought capable of limiting plant growth and compromising yield. This is important because significant water shortages during flowering and grain filling can cause physiological changes that prompt stomatal opening and closing as well as leaf curling, resulting in premature flower abscission and greater pod abortion (EMBRAPA, 2013).

On two occasions, the maximum temperatures from plant emergence to the end of the vegetative

Rev. Caatinga, Mossoró, v. 34, n. 1, p. 99 - 107, jan. - mar., 2021 
stage exceeded $30{ }^{\circ} \mathrm{C}$ for four consecutive days and from the onset of flowering to the end of grain filling there were five periods (3, 4, 7, 8 and 11 days) of three or more consecutive days with temperatures above $30^{\circ} \mathrm{C}$ (Figure 1). As such, plants were likely exposed to heat stress during the reproductive phase.

Although the ideal temperature for soybean vegetative growth is around $30{ }^{\circ} \mathrm{C}$, the optimal temperature for the reproductive phase is about $26{ }^{\circ} \mathrm{C}$ (HATFIELD et al., 2011). At temperatures between 22 and $30{ }^{\circ} \mathrm{C}$, soybean can maintain consistent pod and grain growth rates, but higher temperatures are harmful (SIEBERS et al., 2015). The damage caused by high temperatures depends on the plant genotype and the severity and duration of heat stress (BUCHANAN; GRUISSEM; JONES, 2015). In soybean, temperatures above $30{ }^{\circ} \mathrm{C}$ for relatively short periods ( 3 to 5 days), particularly during the reproductive phase, promote a linear reduction in yield components, significantly compromising grain yield at $35^{\circ} \mathrm{C}$ (PUTEH et al., 2013; SIEBERS et al., 2015).

The final plant population was not influenced by the treatments, as shown in Figure 2 (A1 and A2). The average population size at harvest was 294,000 plants per hectare, within the recommended range for the M6410 IPRO cultivar.

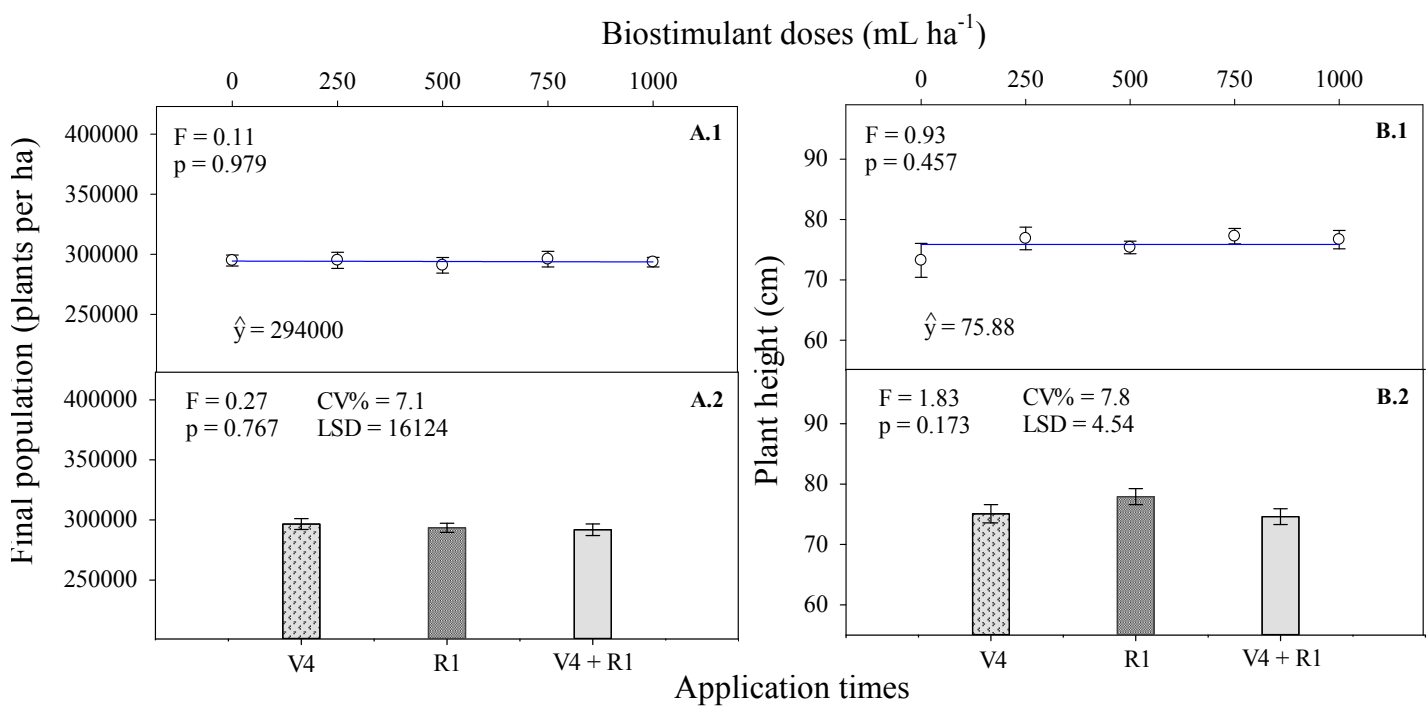

Figure 2. Final population and plant height of soybean as a function of application times and doses of a seaweed-based (Ecklonia maxima) foliar-applied biostimulant. Error bars indicate \pm standard error of the mean, $\mathrm{n}=20$ for application times and $\mathrm{n}=12$ for doses.

Although the biostimulant studied here contains auxins (STIRK et al., 2004) and can therefore potentially affect plant height (TAIZ et al., 2017), and other authors have reported an increase in this variable with the application of seaweed extracts in different crops (SILVA et al., 2010; KASEKER et al., 2014; BACKES et al., 2017), this effect was not independent of biostimulant dose and application time (Figure 2, B1 and B2). However, the aforementioned authors studied the effects of Ascophyllum nodosum application, whereas the present study used a biostimulant made from Ecklonia maxima extract.

It is important to underscore that although greater plant height may result in more nodes per plant, which favors crop yield, this can also increase plant susceptibility to lodging, a common problem in commercial crops that ultimately limits production, compromises grain quality and affects the efficiency of mechanized harvesting (SILVA et al., 2008). Although lodging was not observed in the present study, average plant height was $75.9 \mathrm{~cm}$ (Figure 2 B1), considered adequate for mechanized soybean harvesting according to Bonetti (1983), who reported that height greater than or equal to $65 \mathrm{~cm}$ is desirable for this crop.

The rise in biostimulant doses resulted in a linear increase in the average number of branches per plant. The highest dose $\left(1000 \mathrm{~mL} \mathrm{ha}^{-1}\right)$ produced 4.2 branches per plant, whereas those not sprayed with biostimulant exhibited an average of 3.6 branches per plant (Figure 3 A1). Application time also showed a significant effect for this variable, with foliar spraying at the onset of flowering (R1) resulting in a larger number of branches per plant compared to application in the vegetative stage alone (Figure 3 A2). Intermediate values were recorded for split application in stages V4 and R1. It is important to note that because soybean has an indeterminate growth habit, branching may continue after the onset of flowering. 


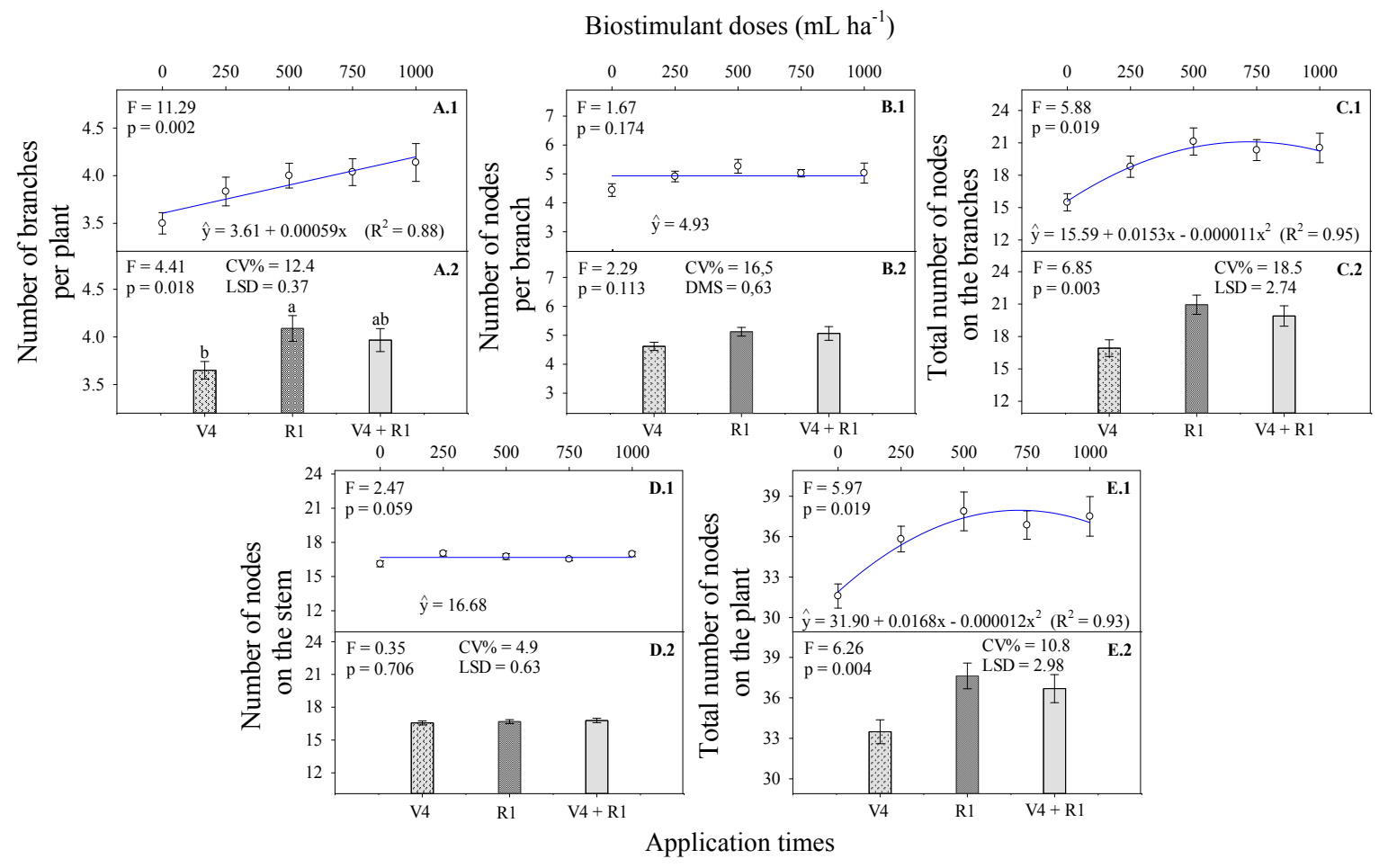

Figure 3. Number of branches per plant, nodes per branch, nodes on the stem and total number of nodes in soybean plants as a function of application times and doses of a foliar-applied seaweed-based (Ecklonia maxima) biostimulant. Error bars indicate \pm standard error of the mean, $\mathrm{n}=20$ for application times and $\mathrm{n}=12$ for doses. Different letters indicate a significant difference between application times according to Tukey's test $(\alpha=0.05)$.

Although the treatments did not affect the average number of reproductive nodes per branch (Figure 3, B1 and B2), the total number on each plant was significantly influenced by biostimulant doses (Figure $3 \mathrm{C} 1$ ), albeit with no differences between application times (Figure $3 \mathrm{C} 2$ ) or interaction between treatments. The increase in biostimulant doses raised the number of nodes up to a dose of $695 \mathrm{~mL} \mathrm{ha}^{-1}$ (Figure $3 \mathrm{C}$ ), which promoted a five-fold increase in this variable, with plants that received this dose exhibiting 21 nodes compared to only 16 nodes in untreated plants.

The treatments had no significant effect on the average number of nodes (Figure 3, D1 and D2); however, the total number of nodes per plant was significantly influenced by biostimulant doses. This variable increased with higher biostimulant doses, regardless of application time (Figure 3, E1 and E2), up to $700 \mathrm{~mL} \mathrm{ha}^{-1}$. At this dose, plants exhibited approximately 38 nodes, whereas untreated plants displayed 32 .

The results obtained for number of branches and nodes may be due to the presence of cytokinins in Ecklonia maxima extract (STIRK et al., 2004), since this plant hormone stimulates axillary bud growth (TAIZ et al., 2017). No studies were found in the literature that investigate the influence of foliar application of seaweed extracts on these variables in soybean crops. However, Kavalcol et al. (2014) analyzed a plant growth regulator based on cytokinin, gibberellin and auxin (Stimulate $\left.{ }^{\circledR}\right)$ and also found that foliar application during the reproductive phase increased the number of branches in soybean plants.

An increase in the number of nodes is relevant because it may lead to a larger number of pods (SANTOS, 2008) and therefore greater yields. As such, these parameters are widely used to select genotypes for high yields (CARVALHO et al., 2002). Albrecht et al. $(2011,2012)$ studied a growth regulator containing cytokinin, gibberellin and auxin (Stimulate ${ }^{\circledR}$ ) in soybean crops and also observed a positive effect up to a certain dose. The authors reported that high doses of products with these characteristics can cause negative physiological effects due to hormonal imbalance.

In regard to the number of flowers on the main stem, biostimulant doses resulted in significant increases in this variable regardless of application time (Figure 4, A1 and A2) up to $632 \mathrm{~mL} \mathrm{ha}^{-1}$, with values declining thereafter (Figure $4 \mathrm{~A} 1$ ). At this dose, there were approximately six flowers on the main stem in relation to untreated plants, with the same observed for number of pods on the stem (Figure 4, B1 and B2). The number of pods rose up to a biostimulant dose of $625 \mathrm{~mL} \mathrm{ha}^{-1}$ (Figure $4 \mathrm{~B} 1$ ), which resulted in around 29 pods on the stem, five more than in untreated plants. 

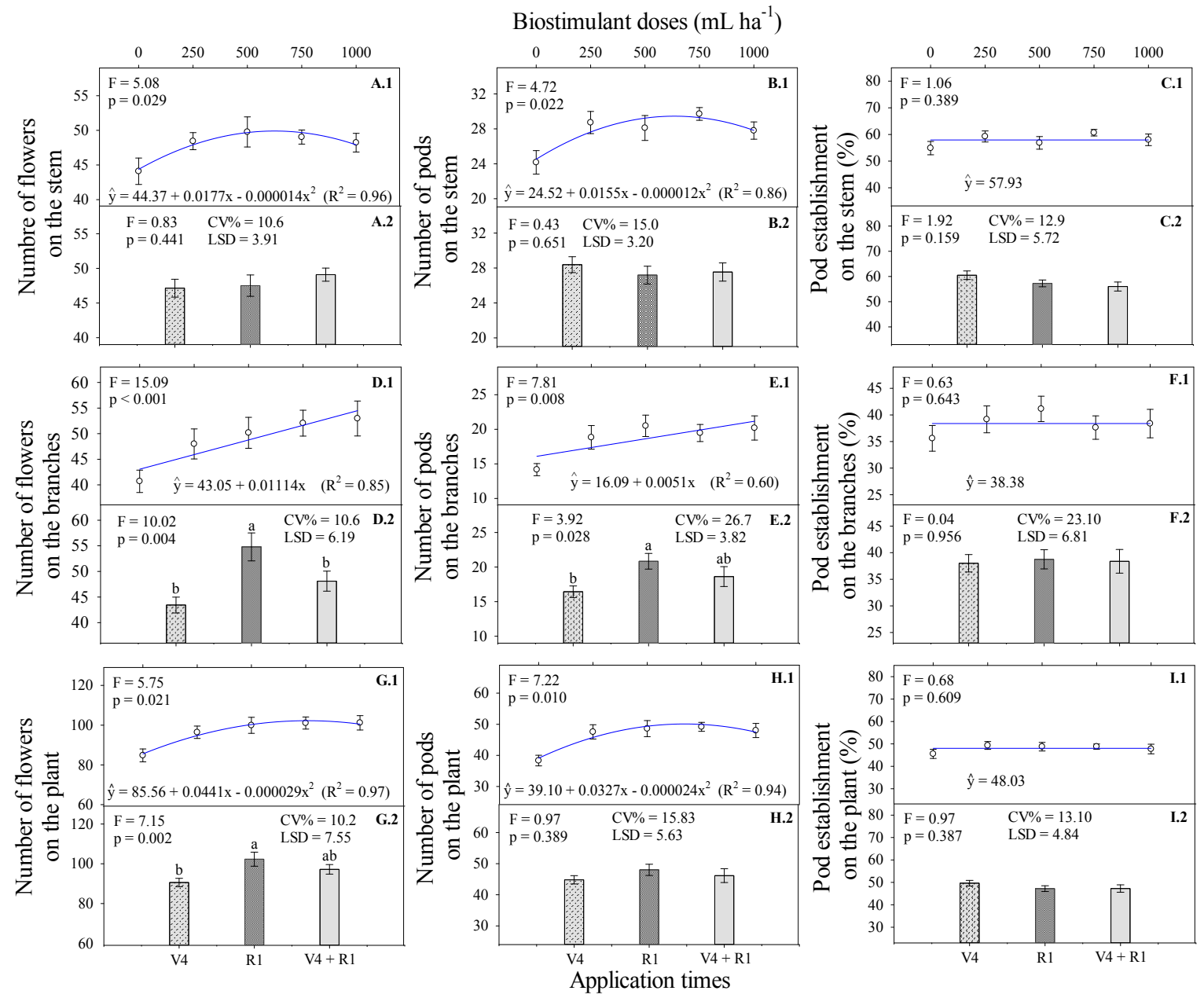

Figure 4. Number of flowers, pods and pod establishment on the stem, branches and whole plant in soybean as a function of application times and doses of leaf-applied seaweed-based (Ecklonia maxima) biostimulant. Error bars indicate \pm standard error of the mean, $\mathrm{n}=20$ for application times and $\mathrm{n}=12$ for doses. Different letters indicate a significant difference between application times according to Tukey's test $(\mathrm{a}=0.05)$.

The rise in biostimulant doses caused a significant linear increase in the average number of flowers on the branches, with the highest dose resulting in around 54 flowers, 11 more than in untreated plants. With respect to application times, higher values were recorded for this variable for foliar spraying in phenological stage R1 (Figure 4, D1 and D2). The same was observed for the number of pods on the branches (Figure 4, E1 and E2); however, the best application time for this variable was in R1 as opposed to V4.

Biostimulant doses also had a significant effect on the total number of flowers and pods (Figure $4 \mathrm{G} 1$ and $\mathrm{H1}$ ), with increases in these variables up to 760 and $681 \mathrm{~mL} \mathrm{ha}^{-1}$, respectively. At these doses, plants exhibited 102 flowers and 50 pods, while untreated plants displayed around 86 flowers and 39 pods. For application time, a significant effect was only observed for number of flowers per plant and the best results were obtained for application in R1 when compared to V4 (Figure $4, \mathrm{G} 2)$.

Similar results were reported by Kocira, Kornas and Kocira (2013), who found that foliar spraying of Ecklonia maxima extract (Kelpak ${ }^{\circledR}$ ) influenced the number of pods in common bean plants (cv. 'Aura'), with concentrations of $0.2 \%$ and $0.4 \%$ applied only once to plants exhibiting 2-3 leaves in 2010 and 2011, respectively, producing the highest number of pods.

Given that rainfall was adequate but high temperatures $\left(30\right.$ to $33{ }^{\circ} \mathrm{C}$ ) were recorded over relatively long periods ( 3 to 11 days) during the reproductive phase, the biostimulant may have mitigated the harmful effects of heat. However, the larger number of reproductive structures obtained with biostimulant application may be related to a hormonal effect due to the presence of auxins and cytokinins. Auxins promote the growth of pollen tubes (ALONI et al., 2006) and reproductive 
structures such as flowers and fruits, while cytokinins act in cell division, common in the initial stages of reproductive structures, as well as the translocation of photoassimilates and nutrient mobilization to sinks (FAGERIA; BALIGAR; CLARK, 2006; BUCHANAN; GRUISSEM; JONES, 2015).

Analysis of the results shown in Figure $4(\mathrm{C} 1$ and $\mathrm{C} 2, \mathrm{~F} 1$ and F2, I1 and I2) demonstrates that the treatments had no significant effect on pod establishment on the stem, branches, and whole plant. Since biostimulant application increased the number of flowers and pods on plants, it can be inferred that analysis of the establishment percentage alone is insufficient to assess the effects of biostimulant on flowering and pod abortion.

Biostimulant doses and application times did not affect 100 grain weight (Figure $5 \mathrm{~A} 1$ and A2). Kocira et al. (2018) found that foliar application of Ecklonia maxima extract (Kelpak ${ }^{\circledR}$ ) influenced 1000 grain weight in common bean plants (cv. 'Aura'), with a concentration of $0.4 \%$ applied at the onset of flowering when plants displayed 2-3 leaves, resulting in higher 1000 grain weight in relation to no biostimulant. However, as observed here, these same authors reported that the biostimulant did not influence the 1000 grain weight of the Toska common bean cultivar.

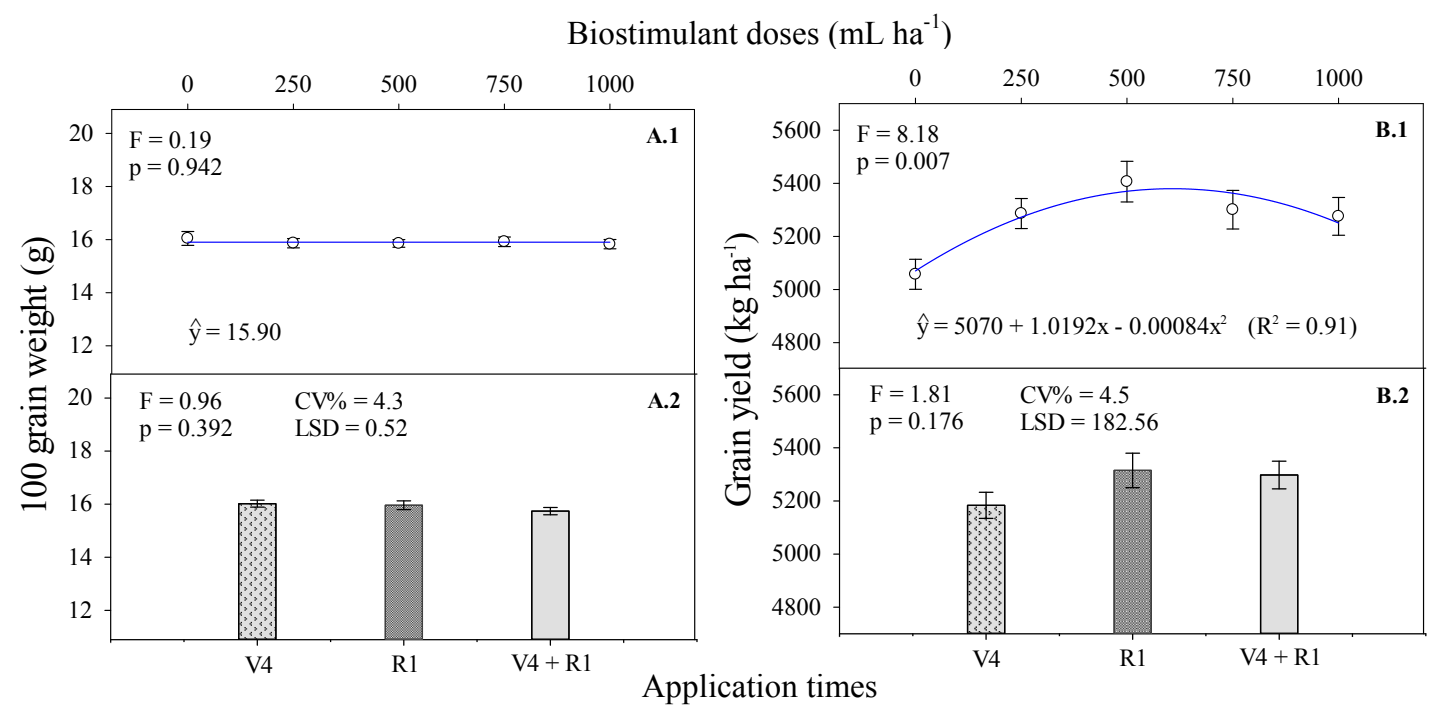

Figure 5. Yield and 100 grain weight of soybean as a function of application times and doses of a seaweed-based (Ecklonia maxima) foliar-applied biostimulant. Error bars indicate \pm standard error of the mean, $\mathrm{n}=20$ for application times and $\mathrm{n}=12$ for doses.

An effect was observed on yield independent of application time (Figure 5, B1 and B2). Analysis of Figure 5 (B1) showed an increase in this variable up to $607 \mathrm{~mL} \mathrm{ha}^{-1}$ of biostimulants, which resulted in a maximum grain yield of $5379 \mathrm{~kg} \mathrm{ha}^{-1}$, that is, 309 $\mathrm{kg} \mathrm{ha}{ }^{-1}$ more than that obtained in the control treatment (no biostimulant). Higher doses prompted a decline in soybean yield.

Kocira, Kornas and Kocira (2013) and Kocira et al. (2018) reported that Ecklonia maxima extract $\left(\right.$ Kelpak $\left.^{\circledR}\right)$ influenced 1000 grain weight in common bean plants regardless of the cultivar used, particularly when applied to plants with 2-3 leaves, with the optimal concentration varying according to the growing season and cultivar. Similarly, Rathore et al. (2009) found that increasing doses of red sea moss extract (Kappaphycus alvarezii) applied to soybean leaves 30 and 60 days after sowing produced higher grain yields, which they attributed to the improvement in yield components (number of pods, number of grains per pod and 1000 grain weight).
Unlike our findings, Albrecht et al. (2011) observed significant differences between phenological growth stages in soybean, obtaining higher yields with biostimulant application in the reproductive phase when compared to its vegetative counterpart.

There are conflicting results in the literature regarding the effect of biostimulants and growth regulators on agricultural crops. For example, Batista Filho et al. (2013) used a biostimulant in soybean and obtained increases in yield components such as number of pods, number of grains per pod and final yield, whereas Galindo et al. (2015) studied Ascophyllum nodosum extract in maize and found no increase in yield or yield components.

Bertolin et al. (2010) investigated the effect of foliar application of a plant growth regulator in soybean and obtained a larger number of pods and $37 \%$ higher yield than controls. Similarly, Albrecht et al. (2011) reported that application of a bioregulator raised soybean yield and the number of pods. However, Bastos et al. (2016) found that 
Durvillaea potatorum did not influence yield components in bean plants. As such, when assessing the efficiency of biostimulants in agricultural crops, it is important to consider a variety of factors, such as the seaweed species, other components of the commercial product (e.g. nutrients), crop, dose and application time.

\section{CONCLUSIONS}

Foliar application of a Ecklonia maximabased biostimulant increased the number of flowers, nodes, branches, and pods per plant, thereby raising the grain yield of the soybean crop. A biostimulant dose of $607 \mathrm{~mL} \mathrm{ha}^{-1}$ produced the highest grain yield (5379 $\mathrm{kg} \mathrm{ha}^{-1}$ ) and application in R1 the largest number of flowers and pods on branches.

\section{REFERENCES}

ALBRECHT, L. P. et al. Biorregulador na composição química e na produtividade de grãos de soja. Revista Ciência Agronômica, 43: 774-782, 2012.

ALBRECHT, L. P. et al. Manejo de biorregulador nos componentes de produção e desempenho das plantas de soja. Bioscience Journal, 27: 865-876, 2011.

ALONI, R. et al. Role of auxin in regulating Arabidopsis flower development. Planta, 223: 315-328, 2006.

BACKES, C. et al. Aplicação foliar de extrato de alga na cultura da batata. Revista de Agricultura Neotropical, 4: 53-57, 2017.

BARBOSA, J. C.; MALDONADO JÚNIOR, W. AgroEstat: sistema para análises estatísticas de ensaios agronômicos. Versão 1.0. Jaboticabal, SP: Unesp, 2010.

BASTOS, F. J. C. et al. Common bean yield under water suppression and application of osmoprotectants. Revista Brasileira de Engenharia Agrícola e Ambiental, 20: 267-701, 2016.

BATISTA FILHO, C. G. et al. Efeito do Stimulate nas características agronômicas da soja. Acta Iguazu, 2: 76-86, 2013.

BATTACHARYYA, D. et al. Seaweed extracts as biostimulants in horticulture. Scientia Horticulturae, 196: 39-48, 2015.

BECK, H. E. et al. Present and future Köppen-
Geiger climate classification maps at 1-km resolution. Scientific Data, 1: 1-12, 2018.

BERTOLIN, D. C. et al. Aumento da produtividade de soja com a aplicação de bioestimulantes. Bragantia, 69: 339-347, 2010.

BONETTI, L. P. Cultivares e seu melhoramento genético. In: VERNETTI, F. J. (Ed.). Soja: genética e melhoramento. Campinas, SP: Fundação Cargill, 1983. v. 2, cap. 3, p. 741-794.

BUCHANAN, B. B.; GRUISSEM, W.; JONES, R. L. Biochemistry and molecular biology of plants. 2. ed. West Sussex, UK: Wiley Blackwell, 2015. $1280 \mathrm{p}$

CARVALHO, C. G. P. et al. Correlação e análise de trilha em linhagens de soja semeadas em diferentes épocas. Pesquisa Agropecuária Brasileira, 37: 311 $-320,2002$.

EMPRESA BRASILEIRA DE PESQUISA AGROPECUÁRIA - EMBRAPA. Tecnologias de Produção de Soja - Região Central do Brasil 2014. 1. ed. Londrina, PR: Embrapa Soja, 2013. 265 p.

FAGERIA, N. K.; BALIGAR, V. C.; CLARK, R. B. Physiology of crop production. New York: The Haworth. 2006. 345 p.

GALINDO, F. S. et al. Desempenho agronômico de milho em função da aplicação de bioestimulantes à base de extrato de algas. Tecnologia \& Ciência Agropecuária, 9: 13-18, 2015.

HATFIELD, J. L. et al. Climate impacts on agriculture: implications for crop production. Agronomy Journal, 103: 351-370, 2011.

KASEKER, J. F. et al. Alteração do crescimento e dos teores de nutrientes com utilização de fertilizante organomineral em cenoura. Revista Ceres, 61: 964969,2014

KAVALCOL, S. A. F. et al. Desenvolvimento da soja com aplicações de hormônios em diferentes densidades de cultivo. Revista Brasileira de Agropecuária Sustentável, 4: 112-116, 2014.

KOCIRA, A.; KORNAS, R.; KOCIRA, S. Effect assessment of Kelpak SL on the bean yield (Phaseolus vulgaris L.). Journal of Central European Agriculture, 14: 545-554, 2013.

KOCIRA, A. et al. Enhancement of yield, nutritional and nutraceutical properties of two common bean cultivars following the application of seaweed extract (Ecklonia maxima). Saudi Journal of 
Biological Sciences, 25:563-571, 2018.

LIU, F.; JENSEN C. R.; ANDERSEN, M. N. Drought stress effect on carbohydrate concentration in soybeans leaves and pods during early reprodutctive development: its implication in altering pod set. Field Crops Research, 86: 1-13, 2004.

PUTEH, A. B. et al. Soybean [Glycine $\max (\mathrm{L}$.) Merrill] seed yield response to high temperature stress during reproductive growth stages. Australian Journal of Crop Science, 7: 1472-1479, 2013.

RATHORE, S. S. et al. Effect of seaweed extract on the growth, yield and nutrient uptake of soybean (Glycine max) under rainfed condition. South African Journal of Botany, 75: 351-355, 2009.

RENGASAMY, K. R. R. et al. Eckol - a new plant growth stimulant from the brown seaweed Ecklonia maxima. Journal of Applied Phycology, 27: 581587, 2015.

SANTOS, H. G. et al. Sistema brasileiro de classificação de solos. 5. ed. Brasília, DF: Embrapa, 2018.353 p.

SANTOS, T. L. Soja. In: CASTRO, P. R. C.; KLUGE, R. A.; SESTARI, I. (Eds.). Manual de fisiologia vegetal: fisiologia dos cultivos. Piracicaba, SP: Agronômica Ceres, 2008. v. 1, cap. 1, p. 157-175.

SIEBERS, M. et al. Heat waves imposed during early pod development in soybean (Glycine max) cause significant yield loss despite a rapid recovery from oxidative stress. Global Change Biology, 21: 3114-3125, 2015.

SILVA, A. F. et al. Densidades de plantas daninhas e épocas de controle sobre os componentes de produção da soja. Planta Daninha, 26: 65-71, 2008.

SILVA, C. P. et al. Aplicação foliar do extrato de alga Ascophyllum nodosum e do ácido glutâmico no desenvolvimento inicial de crisântemos (Dendranthema morifolium (Ramat.) Kitam.) em vasos. Revista Brasileira de Horticultura Ornamental, 16: 179-181, 2010.

STIRK, W. A. et al. Changes in cytokinin and auxin concentrations in seaweed concentrates when stored at an elevated temperature. Journal of Applied Phycology, 16: 31-39, 2004.

TAIZ, L. et al. Fisiologia e desenvolvimento vegetal. 6. ed. Porto Alegre, RS: Artmed, 2017. 888 p.
THOMAS, A. L. Soja: tipos de crescimento da planta. Porto Alegre, RS: UFRGS. 2018. 59 p.

YAKHIN, O. I. et al. Biostimulants in plant science: a global perspective. Frontiers in Plant Science, 7: $1-32,2017$. 